\title{
Profesora Lucía Antonieta Lorca, una vida dedicada a la Extensión y al Desarrollo Rural
}

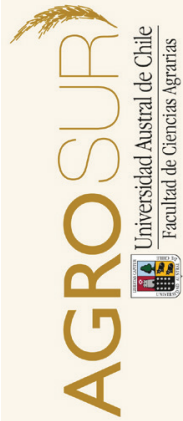

\author{
Professor Lucía Antonieta Lorca, a life dedicated to Extension \\ and Rural Development
}

\author{
Juan Lerdon ${ }^{a *}$ \\ ${ }^{a}$ Instituto de Economía Agraria, Facultad de Ciencias Agrarias, Universidad Austral de Chile. Casilla 567, Valdivia, Chile. \\ *Autor de correspondencia: jlerdon@uach.cl
}

E D I T O R I A L

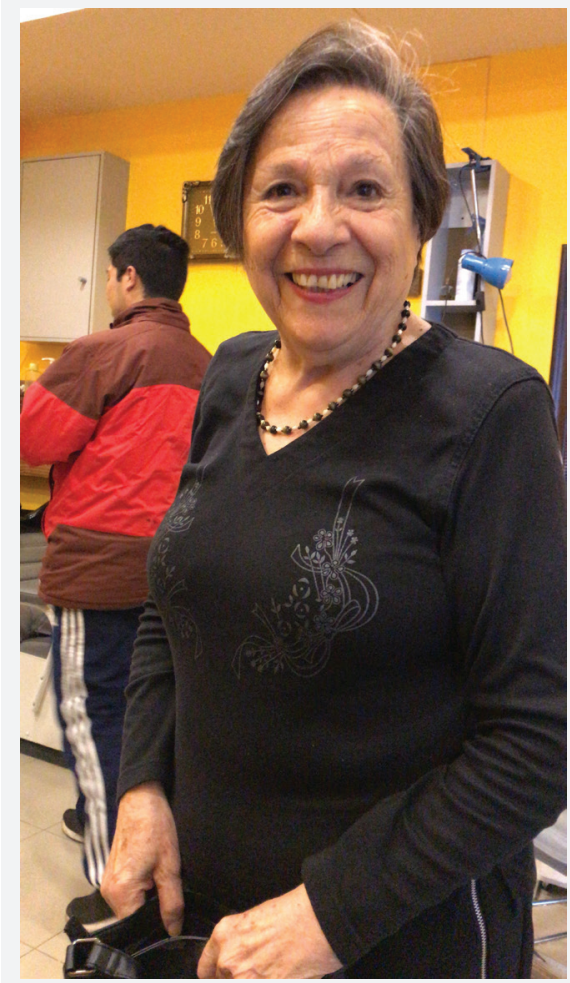

Between 1958 and 1963, Professor Lucía Antonieta Lorca graduated in Agronomy in Venezuela, where she specialised in Agricultural Extension and Social Sciences.

In 1966, after validating her degree in Chile, it was in the Faculty of Agricultural Sciences of the Austral University of Chile that she offered, for the first time in the country, an Agricultural Extension course with a marked emphasis on Rural Development - taking an approach on the education of the farmer, based on his needs in order to improve agriculture and the living conditions of rural people.

In 1971 Professor Lorca did a Master's degree in Extension at Washington State University. During this period she was able to find out about the organization, function and success of the Extension activity in the United States agriculture and life in the rural sectors, which allowed the development of other sectors of the North American economy.

In 1982, she obtained a grant from the Government of Taiwan and spent three months studying Rural Development at the Land Reform and Rural Development Institute. This training provided her a close-up view of one of the few successful agrarian reform processes in the world and its model of integral development.

She worked along Professor Carlos Amtmann during a period of three years to design a down to earth, interesting and empowering curriculum for the university professionals doing the Master's level in Rural Development. Teachers and authorities were also involved in the process to make this a reality. The support of the Inter-American Institute of Agrarian Sciences (IICA) was obtained through its representative Hernán da Costa Fiori, who also made important contributions. This postgraduate course was first offered in 1985, being attended by professionals from the Health, Education, Economics, Social Sciences and Silvoagricultural Sciences sectors who came from many Latin American countries, the United States and Spain. The coordination of this Master course was in charge of Professor Lucía Lorca from 1985 to 1992, when she retired.

Since then, Professor Lorca has actively collaborated in activities developed in the Máfil Commune, both in the organization of older people and in the role of Cultural Delegate of the Commune before national cultural councils.

How did Toña, as we nickname her, become someone faithful to his convictions? Undoubtedly his extroverted and persevering personality, his holistic vision of rural development and agricultural extension, her closeness to her surroundings and in particular to her students, always inspiring them to become better professionals, to overcome their weaknesses and adversities. Many generations of students of the Faculty of Agricultural Sciences of the Universidad Austral de Chile had the privilege of having her as a teacher, and her teachings have accompanied us permanently, both in the professional and human fields.

To this day, at 87 years old, she is still an active woman, proud that the Magister of which she was co-creator has a scholarship that bears her name, fully attentive to her environment and the Faculty of Agricultural Sciences as well as the Rural Development in its most integral sense, and especially, the Curriculum of the career of Agronomy, and how Extension should be incorporated in the professional development of future generations. 


\section{EDITORIAL}

Entre 1958 y 1963, la profesora Lucía Antonieta Lorca terminó su formación agronómica en Venezuela donde eligió como Mención el área de Extensión Agrícola y Ciencias Sociales.

En el año 1966, luego de haber revalidado su título en Chile, en la Facultad de Ciencias Agrarias de la Universidad Austral de Chile ofreció por primera vez en el país el curso de Extensión Agrícola con un marcado énfasis en Desarrollo Rural - un enfoque de educación al agricultor partiendo de sus necesidades para lograr el mejoramiento de la agricultura y las condiciones de vida de los pobladores rurales.

En 1971 la profesora Lucía Lorca se graduó de Master of Extension en Washington State University. Durante este periodo pudo informarse de la organización, función y éxito de la actividad de Extensión en la agricultura de Estados Unidos y de la vida de los sectores rurales, lo que permitió el desarrollo de otros sectores de la economía norteamericana.

En 1982, mediante una beca otorgada por el Gobierno de Taiwán, permaneció tres meses estudiando Desarrollo Rural en el Instituto Land Reform and Rural Development. Este entrenamiento le permitió conocer uno de los pocos procesos de Reforma Agraria exitosos del mundo y su modelo de desarrollo integral.

Durante un periodo de tres años, junto al profesor Carlos Amtmann, planificaron un currículum aterrizado, interesante y habilitador para muchos profesionales universitarios a nivel de Magíster en Desarrollo Rural. Se involucró a profesores y autoridades para poder concretarlo. Se logró el apoyo del Instituto Interamericano de Ciencias Agrarias (IICA), a través de su representante Hernán da Costa Fiori, quien hizo importantes contribuciones. En 1985, se ofreció por primera vez este postgrado al que han concurrido profesionales de la Salud, Educación, Economía, Ciencias Sociales y Ciencias Silvoagropecuarias provenientes de gran parte de Latinoamérica, Estados Unidos y España. La coordinación de este Magíster estuvo a cargo de la profesora Lucía Lorca desde 1985 a 1992, fecha en que jubiló.

A partir de entonces, la profesora Lorca ha colaborado activamente en trabajos de la Comuna de Máfil, tanto en la organización de los adultos mayores como en el rol de Delegada Cultural de la Comuna en los Cabildos culturales nacionales.

¿Qué hizo de Toña, como le decimos sus más cercanos, una persona fiel a sus convicciones? Sin lugar a dudas su personalidad extrovertida y perseverante, su visión holística sobre el desarrollo rural y la extensión agrícola, su cercanía con el entorno, en particular con sus estudiantes, motivándolos siempre a ser mejores personas, a superar sus debilidades y las adversidades. Muchas generaciones de estudiantes de la Facultad de Ciencias Agrarias de la Universidad Austral de Chile, tuvieron el privilegio que tenerla como maestra, cuyas enseñanzas nos han acompañado permanentemente, tanto en el ámbito profesional como humano.

Hasta el día de hoy, con 87 años, es una mujer activa, orgullosa de que el Magíster del cual fue co-creadora tenga una Beca que lleve su nombre, plenamente atenta a su entorno y pendiente de la Facultad de Ciencias Agrarias, del Desarrollo Rural en su acepción más integral, y muy especialmente, del Curriculum de la carrera de Agronomía, y de la forma en que la Extensión debiera incorporarse en la formación para el desarrollo profesional de las futuras generaciones. 